\title{
Article \\ Hybrid Bermudagrass and Tall Fescue Turfgrass Irrigation in Central California: II. Assessment of NDVI, CWSI, and Canopy Temperature Dynamics
}

\author{
Amir Haghverdi ${ }^{1, *(\mathbb{D}, \text { Maggie Reiter }}{ }^{2,3}\left[\right.$, Amninder Singh ${ }^{1}\left(\mathbb{D}\right.$ and Anish Sapkota ${ }^{1}$ \\ 1 Environmental Sciences Department, University of California Riverside, Riverside, CA 92521, USA; \\ asing075@ucr.edu (A.S.); asapk001@ucr.edu (A.S.) \\ 2 Division of Agriculture and Natural Resources, University of California, Cooperative Extension, \\ Fresno, CA 93710, USA; reit0215@umn.edu \\ 3 Department of Horticultural Science, University of Minnesota, St. Paul, MN 55108, USA \\ * Correspondence: amirh@ucr.edu
}

check for updates

Citation: Haghverdi, A.; Reiter, M.; Singh, A.; Sapkota, A. Hybrid Bermudagrass and Tall Fescue Turfgrass Irrigation in Central California: II. Assessment of NDVI, CWSI, and Canopy Temperature Dynamics. Agronomy 2021, 11, 1733. https://doi.org/10.3390/ agronomy 11091733

Academic Editors:

Aliasghar Montazar and Jose Beltrao

Received: 22 June 2021

Accepted: 26 August 2021

Published: 29 August 2021

Publisher's Note: MDPI stays neutral with regard to jurisdictional claims in published maps and institutional affiliations.

Copyright: (c) 2021 by the authors. Licensee MDPI, Basel, Switzerland. This article is an open access article distributed under the terms and conditions of the Creative Commons Attribution (CC BY) license (https:/ / creativecommons.org/licenses/by/ $4.0 /)$.

\begin{abstract}
As the drought conditions persist in California and water continues to become less available, the development of methods to reduce water inputs is extremely important. Therefore, improving irrigation water use efficiency and developing water conservation strategies is crucial for maintaining urban green infrastructure. This two-year field irrigation project (2018-2019) focused on the application of optical and thermal remote sensing for turfgrass irrigation management in central California. We monitored the response of hybrid bermudagrass and tall fescue to varying irrigation treatments, including irrigation levels (percentages of reference evapotranspiration, $\mathrm{ET}_{\mathrm{o}}$ ) and irrigation frequency. The ground-based remote sensing data included NDVI and canopy temperature, which was subsequently used to calculate the crop water stress index (CWSI). The measurements were done within two hours of solar noon under cloud-free conditions. The NDVI and canopy temperature data were collected 21 times in 2018 and 10 times in 2019. For the tall fescue, a strong relationship was observed between NDVI and visual rating (VR) values in both $2018(r=0.92)$ and $2019(r=0.83)$. For the hybrid bermudagrass, there was no correlation in 2018 and a moderate correlation $(r=0.72)$ in 2019. There was a moderate correlation of 0.64 and 0.88 in 2018 and 2019 between tall fescue canopy minus air temperature difference $(d t)$ and vapor pressure deficit (VPD) for the lower CWSI baseline. The correlation between hybrid bermudagrass $d t$ and VPD for the lower baseline was 0.69 in 2018 and 0.64 in 2019. Irrigation levels significantly impacted tall fescue canopy temperature but showed no significant effect on hybrid bermudagrass canopy temperature. For the same irrigation levels, increasing irrigation frequency slightly but consistently decreased canopy temperature without compromising the turfgrass quality. The empirical CWSI values violated the minimum expected value (of 0 ) $38 \%$ of the time. Our results suggest NDVI thresholds of $0.6-0.65$ for tall fescue and 0.5 for hybrid bermudagrass to maintain acceptable quality in the central California region. Further investigation is needed to verify the thresholds obtained in this study, particularly for hybrid bermudagrass, as the recommendation is only based on 2019 data. No CWSI threshold was determined to maintain turf quality in the acceptable range because of the high variability of CWSI values over time and their low correlation with VR values.
\end{abstract}

Keywords: smart controller; evapotranspiration; autonomous landscape irrigation

\section{Introduction}

The western USA is generally arid and subject to droughts yet is home to some of the largest cities across the nation. Consequently, it is vital to establish water conservation strategies for metropolitan areas to enhance urban water use efficiency and guarantee the long-term sustainability of water resources. Irrigation demand is usually the largest component of total outdoor water use in urban sectors in this region. In the southwestern 
US, landscape water use in the summer month can reach up to $90 \%$ of the total municipal water use [1]. Turfgrass is a large component of urban landscapes that provides valuable recreation areas and ecosystem services [2]. Across the nation, the largest sector of turfgrass is residential lawns. Therefore, developing recommendations for efficient irrigation management of turfgrass is crucial for maintaining urban green infrastructure.

In the last two decades, documented research on urban irrigation management has mainly focused on the implementation of irrigation technologies to enhance irrigation water use efficiency [3-8], the use of low-quality water for irrigation to alleviate freshwater demand [9-11], and the applications of remote sensing (RS) techniques to detect drought injury and manage irrigation [12-14]. The latter is particularly timely considering the rapidly emerging advancements in novel RS platforms. Some promising results have been reported on the application of multispectral and thermal RS techniques to predict the green leaf area index of turfgrass [12], estimate the crop water stress index (CWSI) [15], calculate the location and rate of urban irrigation [13], and monitor turfgrass water stress and use [14]. For instance, Taghvaeian et al. [14] used ground-based optical and thermal RS to study the quality response, water stress, and water consumption of multiple turfgrass species under different soil and irrigation treatments in northern Colorado, USA. RS helps scale the findings of plot-based research projects providing the decision-making information necessary for assessing the urban irrigation footprint for large metropolitan areas. For instance, Chen et al. [16] used RS techniques plus water use records to estimate that in 2005-2007, 7\% of the postal carrier routes in Los Angeles, California were overwatered in dry years and $43 \%$ were overwatered in wet years.

Monitoring canopy temperature can help quantify plant water stress in a fast and non-destructive way, which could be used for efficient irrigation management [17]. In addition, measuring canopy temperature variations due to deficit irrigation is necessary to understand the tradeoffs between water conservation and the vital role of the irrigated urban landscape to mitigate the urban heat island phenomenon. The irrigated landscape, through the process of evapotranspiration, can reduce daytime heat storage and enhance nighttime cooling, thereby moderating the climate of urban areas and creating localized cool islands [18]. Bonfils and Lobell [19] showed the significant cooling effect that irrigation expansion has had on summertime average daily daytime temperatures in California. Broadbent et al. [20] studied the cooling benefits of irrigation in a suburb of Adelaide, Australia and found that the diurnal average air temperature was reduced by up to $2.3^{\circ} \mathrm{C}$, but that increasing irrigation had a non-linear effect on cooling. Wang et al. [21] reported $4.52 \pm 0.77 \mathrm{~mm}$ day $^{-1}{ }^{\circ} \mathrm{C}^{-1}$ surface air cooling in urban areas over the contiguous United States due to irrigation.

CWSI is a dimensionless temperature-based index [22] that has shown success in quantifying turfgrass water stress [14]. The empirical approach of Idso et al. [22] requires establishing the lower and upper-temperature baselines for non-water-stressed and nontranspiring conditions, respectively. The reported CWSI baselines for turfgrass in the literature vary widely. Therefore, specific baselines for each climatic region should be developed.

In the first part of this study [23], we used a visual rating (VR) to assess turfgrass response to a wide range of irrigation scenarios in central California. VR is the traditional method of rating turfgrass quality ranging from 1 (worst) to 9 (best) that has been used by researchers and turfgrass managers worldwide for turfgrass evaluation [24]. However, it is subjective and can be inaccurate since different observers may rate the turfgrass differently, or even an identical evaluator may give different ratings to the same plots over time, and therefore, such quality ratings are nonreproducible $[25,26]$. RS is an alternative approach that can provide a more accurate, consistent, and reliable evaluation of overall turfgrass quality, growth, and health. In addition, the recent advancement in unmanned aerial vehicles makes RS a superior method for scouting and identifying drought injury on large irrigated turfgrass areas such as parks and golf courses. The normalized difference vegetation index (NDVI) has been used as a replacement to assess the response of turfgrass 
to irrigation scenarios and has been shown to be well correlated with the visual rating of different grass species, including 'Dynasty' tall fescue [27] and 'Tifgreen' hybrid bermudagrass [8]. In addition, Bremer et al. [28] reported high correlation values between NDVI and percentage green cover $(r=0.91)$ and shoot density $(r=0.88)$ using data obtained from multiple cool-season grass species.

This study was conducted to (i) monitor the changes in NDVI and canopy temperature of tall fescue and hybrid bermudagrass under varying irrigation treatments (amount and frequency) in central California, (ii) develop empirical CWSI and study its variability over time for both turfgrass species, and (iii) investigate the relationship between NDVI and visual rating values reported in the companion paper [23]. We focused on both cool-season and warm-season turfgrass species in this study because they are grown in different settings in urban areas in central California. Warm-season species are considered superior because of their relatively lower water requirement, but they could be less appealing to certain groups since they go dormant over the winter.

\section{Materials and Methods}

\subsection{Experimental Site}

This study was conducted at the University of California Agricultural and Natural Resources Kearney Research and Extension Center ( $36^{\circ} 36^{\prime} 02.2^{\prime \prime}$ N 119 $30^{\prime} 38.8^{\prime \prime}$ W) in Parlier, California (Figure 1). The study site consisted of 36 plots. Each plot was roughly 14 $\mathrm{m}^{2}$ with an approximately $60 \mathrm{~cm}$ border between the adjacent plots.

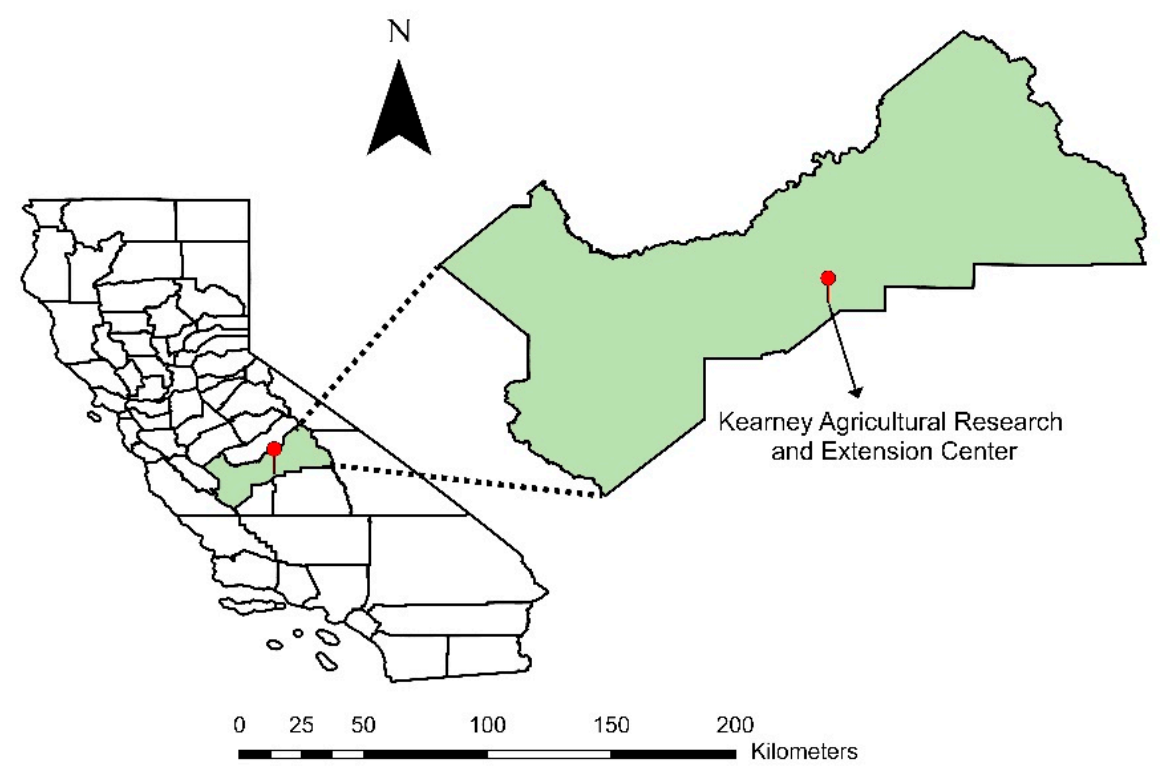

Figure 1. The location of the study area.

Figure 2a depicts the long-term mean cumulative reference evapotranspiration $\left(\mathrm{ET}_{\mathrm{o}}\right)$ and precipitation data measured by the California Irrigation Management Information System (CIMIS) weather station \#75 located close to the study site. Long-term annual weather data show that $\mathrm{ET}_{\mathrm{o}}$ is roughly five times greater than the precipitation received in this area. Irrigation is necessary to keep the urban landscape species alive, particularly during the summer months when evaporative demand is highest. The soil at the research site is classified as Hanford fine sandy loam (websoilsurvey.sc.egov.usda.gov, accessed on 27 August 2021). The laboratory analysis of undisturbed samples collected from the top $20 \mathrm{~cm}$ revealed that the available soil water-holding capacity is $0.19 \mathrm{~m}^{3} \mathrm{~m}^{-3}$ for 10 and $1500 \mathrm{kPa}$ that represent field capacity and permanent wilting point, respectively [29]. 


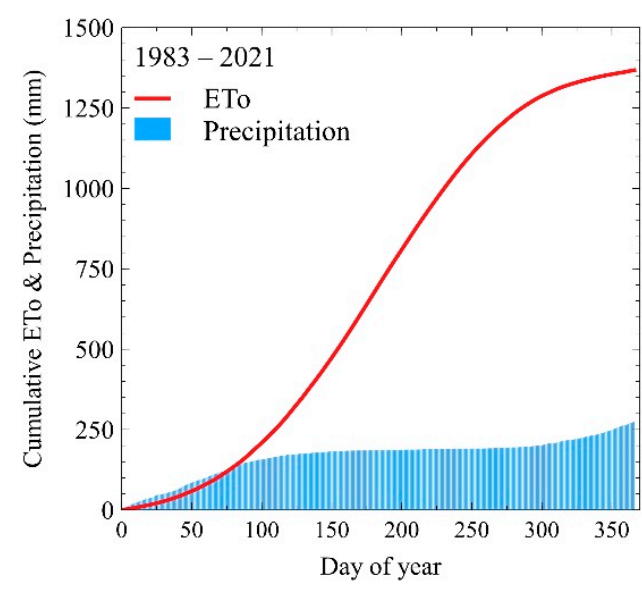

(a)

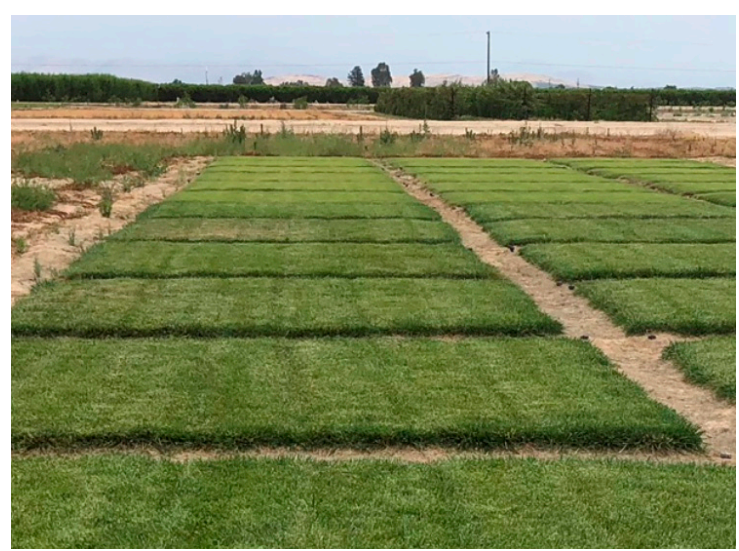

(b)

Figure 2. The long-term mean reference evapotranspiration $\left(\mathrm{ET}_{\mathrm{O}}\right)$ and precipitation trends at the study site from a nearby weather station (a). A photo taken on 30 May 2018 showing the research plots (b).

\subsection{Irrigation Trials}

Two adjacent hybrid bermudagrass ('Latitude 36' Cynodon dactylon (L.) Pers. $\times C$. transvaalensis Burtt-Davy) and tall fescue (A blend of 'PennRK4', 'Rebel XLR', + 'Firecracker SLS' Schedonorus arundinaceus (Schreb.) Dumort.) irrigation trials were arranged in a factorial randomized complete block design with repeated measures of canopy temperature and NDVI. Each trial consisted of 18 plots $(3.7 \mathrm{~m} \times 3.7 \mathrm{~m})$ forming three blocks (replications) to impose six irrigation treatments. To minimize evaporative loss and wind drift, irrigation was done overnight and early morning. In addition, the smart controller performed an automatic run/soak schedule to eliminate runoff and provide enough soak time. All three replications for each treatment were irrigated at the same time by wiring to the same zone on the controller. Each plot was equipped with a TORO 252 Series solenoid valve (Toro Co., Bloomington, MN, USA) supplying water to four Toro O-T-12-QP corner-pop-up 6 ${ }^{\prime \prime}$ sprinkler heads ( $152 \mathrm{~mm}$ tall). The sprinkler nozzles had an operating pressure range and flow rate of 276-517 kPa and 0.02-9.08 $\mathrm{L} \mathrm{min}^{-1}$, respectively. To achieve steady water application, the sprinklers were equipped with factory-installed pressure-compensating discs (Toro Co., Bloomington, MN, USA).

The irrigation treatments consisted of three $\mathrm{ET}_{\mathrm{o}}$-based irrigation levels and two irrigation frequencies (Table 1). A Weathermatic Smartline (SL) 4800 controller (Telsco Industries, Inc., Garland, TX, USA) was used to control irrigation treatments and schedule irrigation throughout the study autonomously. The controller used an onsite temperature sensor and latitude-based solar radiation information to calculate ETo using the Hargreaves and Samani equation [30]. Irrigation efficiency (i.e., low half distribution uniformity) of 0.78 and irrigation precipitation rate of $23 \mathrm{~mm} \mathrm{~h}^{-1}$ was calculated using a catch-cans test performed before conducting the trial in year 1. Irrigation was non-limiting to ensure actively growing, non-stress turfgrass prior to initiating irrigation treatments. The experiment started on 4 May 2018, and data collection ended on 11 September 2018. All plots were switched back to the uniform non-limiting irrigation for recovery before starting the trial on 22 June 2019. On 26 August 2019, the main irrigation pipe broke and flooded the field, forcing the research team to terminate the trial. More information about the irrigation system characteristics and establishment of the plots is provided in the companion paper [23]. 
Table 1. Irrigation treatments throughout the 2-year tall fescue and hybrid bermudagrass irrigation research experiments at the University of California Kearney Research and Extension Center.

2018 Trial, Start: 4 May 2018 । End: 11 September 2018

Target Irrigation Levels ( $\% \mathrm{ET}_{\mathrm{o}}$ ): Tall Fescue: 50\%, 65\%, 80\% | Hybrid Bermudagrass: 40\%, 50\%, 60\%

Irrigation Efficiency: $78 \%$

Watering Days: 2 days per week, 3 days per week

2019 Trial, Start: 22 June 2019 | End: 26 August 2019

Target Irrigation Levels ( $\% \mathrm{ET}_{\mathrm{o}}$ ): Tall Fescue: 50\%, 65\%, 80\% I Hybrid Bermudagrass: 40\%, 50\%, 60\%

Irrigation Efficiency: 78\%

Watering Days: 3 days per week, 7 days per week (no restriction)

The controller used the user-defined "plant type" information to convert $\mathrm{ET}_{\mathrm{o}}$ to irrigation application (irrigation application = plant type $\left.\times \mathrm{ET}_{\mathrm{o}}\right)$. For each treatment, the plant type was calculated as the irrigation levels $\left(\% \mathrm{ET}_{\mathrm{o}}\right)$ divided by the irrigation efficiency of the system.

Table 2 summarizes the irrigation application data. All treatments were over irrigated mainly due to the inaccurate estimation of the irrigation precipitation rate using the catchcans method at the beginning of the trial. The actual applied irrigation rate was calculated at the end of the trial based on the revised irrigation precipitation rate of $18 \mathrm{~mm} \mathrm{~h}^{-1}$. The performance of the smart controller is discussed in detail in the companion paper [23].

Table 2. Target irrigation treatments (T1-T3) versus programmed and applied irrigation levels throughout the 2-year tall fescue and hybrid bermudagrass irrigation research experiments conducted at the University of California Kearney Research and Extension Center.

\begin{tabular}{lcccccc}
\hline & \multicolumn{3}{c}{ Tall Fescue } & \multicolumn{3}{c}{ Hybrid Bermudagrass } \\
\hline Irrigation & T1 & T2 & T3 & T1 & T2 & T3 \\
\hline Treatment & $50 \%$ & $65 \%$ & $80 \%$ & $40 \%$ & $50 \%$ & $60 \%$ \\
Programmed & $64 \%$ & $83 \%$ & $100 \%$ & $51 \%$ & $64 \%$ & $77 \%$ \\
Applied & $83 \%$ & $108 \%$ & $129 \%$ & $65 \%$ & $84 \%$ & $101 \%$ \\
\hline
\end{tabular}

Programmed irrigation levels are equal to target treatment levels divided by the irrigation efficiency of 0.78 (i.e., the low half distribution uniformity of the irrigation system). Applied irrigation levels were recalculated based on the irrigation run time data retrieved from the controller and precipitation rate of $28 \mathrm{~mm}$ day $^{-1}$ measured for the system at the end of the trial.

\subsection{Data Collection and Statistical Analysis}

Figure 3 illustrates an overview of the sensors and tools used in this study and the companion paper [8]. The active light source optical GreenSeeker handheld sensor (Trimble Inc., Sunnyvale, CA, USA) was used to collect NDVI data. The sensor has a measurement range of 0 to 0.99 and a roughly $51 \mathrm{~cm}$ wide oval field of view when held $122 \mathrm{~cm}$ above the ground. Canopy temperature was recorded using the Fluke 64 Max Infrared Thermometer (Fluke Corporation, Everett, WA, USA). According to the manufacturer, the thermometer has a measurement range of -30 to $500{ }^{\circ} \mathrm{C}$ and a spectral band of 8-14 microns with an accuracy of $1.5{ }^{\circ} \mathrm{C}$ or $1.5 \%$ of the reading. The resolution of the thermometer was $0.1{ }^{\circ} \mathrm{C}$ with an $87 \mathrm{~mm}$ field of view when held $150 \mathrm{~cm}$ above the ground. During the data collection, both sensors were held at approximately $1 \mathrm{~m}$ height and moved over the center of each plot $\left(\approx 3-4 \mathrm{~m}^{2}\right)$ while the trigger remained engaged to continuously scan and obtain an average representative value for each plot. The air temperature and relative humidity were recorded using the Fluke 971 Temperature Humidity Meter (Fluke Corporation, Everett, WA, USA) over each experimental plot during the data collection process. According to the manufacturer, the Fluke 971 handheld sensor has a temperature measurement accuracy of $\pm 0.5^{\circ} \mathrm{C}$ in the 0 to $45^{\circ} \mathrm{C}$ range and an $\mathrm{RH}$ measurement accuracy of $\pm 2.5 \%$ in the $10 \%$ to $90 \% \mathrm{RH}$ range. The resolution of the temperature/humidity meter was $0.1^{\circ} \mathrm{C}$ and $0.1 \% \mathrm{RH}$. The measurements were done within two hours of solar noon under cloud-free conditions. The handheld data were collected roughly once a week throughout the trial, 21 times in 2018 (from 30 April to 22 September), and 10 times in 2019 (from 24 June to 26 August). 

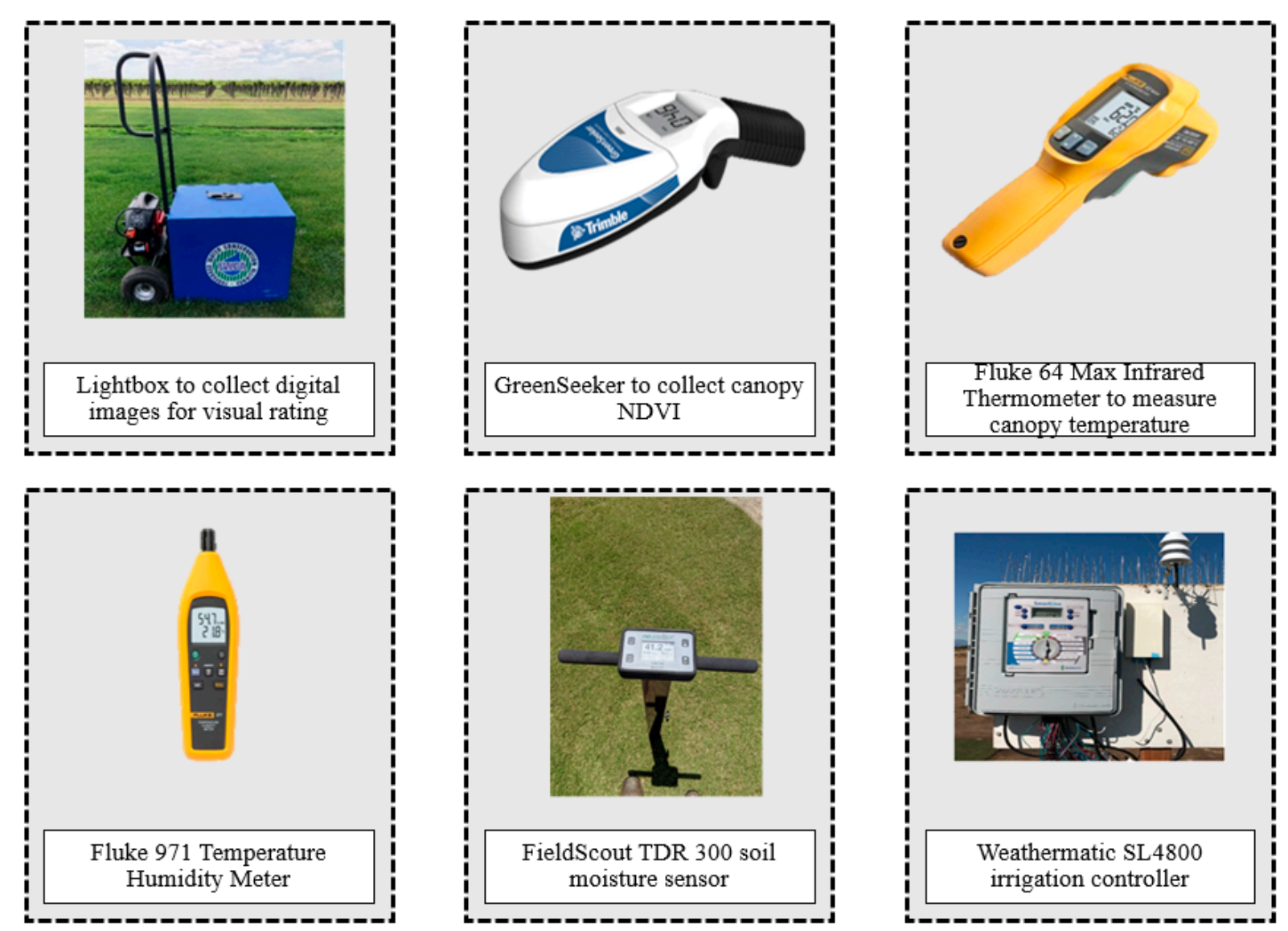

Figure 3. An overview of the sensors and tools used in this study and the companion paper [23].

The NDVI and canopy temperature data were statistically analyzed using PROC GLIMMIX in SAS 9.4 software package (SAS Institute, 2014). The irrigation frequency and duration of the experiment differed in years 1 and 2 . Therefore, each year was independently analyzed for the treatment effects to accommodate differences in experimental duration and irrigation regimes. The fixed effects were the irrigation levels, irrigation frequencies, and the date of data collection. The random effects were block and its interaction with irrigation levels and irrigation frequencies. The treatment effects were considered significant at $p$-values $\leq 0.05$. The plotting software package Veusz 3.3.1 (https:/ / veusz.github.io/, accessed on 27 August 2021) [31] was used to create all graphs. The NDVI data were compared against the turfgrass visual rating (VR) values presented in the companion study [23]. The rating was based on The National Turfgrass Evaluation Program (NTEP) standards [32], with the minimum and maximum scores of 1 and 9 assigned to dead and ideal turfgrass, respectively.

\subsection{Crop Water Stress Index (CWSI)}

The CWSI relies on the temperature difference between the canopy and air, $d t^{\circ} \mathrm{C}$ $(T c-T a)$, and it is defined as:

$$
\text { CWSI }=\frac{d t_{m}-d t_{l b}}{d t_{u b}-d t_{l b}}
$$

where $m, l b$, and $u b$ indicate the measured, lower baseline (non-water-stressed), and upper baseline (non-transpiring) of $d t$, respectively.

The empirical CWSI is based on the linear relationship between the lower baseline temperature difference and vapor pressure deficit (VPD) [22,33]:

$$
d t_{l b}=a(\mathrm{VPD})+b
$$


The VPD is calculated as follows:

$$
\mathrm{VPD}=e_{s}-e_{a}
$$

where $e_{s}$ is the saturation vapor pressure $(\mathrm{kPa})$ and $e_{a}$ is the actual vapor pressure $(\mathrm{kPa})$ calculated as:

$$
\begin{gathered}
e_{s}=0.6108 * \exp \left(\frac{17.27 \times T_{a}}{237.3+T_{a}}\right) \\
e_{a}=(R H / 100) * e_{s}
\end{gathered}
$$

The CWSI was calculated for each species separately in this study. The mean canopy temperature data obtained from the highest irrigation levels were used to estimate the lower baselines over all the well-watered plots of each species. The mean air temperature and RH values collected over all the plots using the handheld Fluke $971 \mathrm{~m}$ were used to calculate VPD. The upper baseline was calculated as the mean temperature difference between air and severely stressed tall fescue grass [17]. The baseline was established using the canopy temperature data collected in both years from a plot of non-irrigated tall fescue turfgrass adjacent to the study field. The non-transpiring canopy temperature was assumed to be similar between tall fescue and hybrid bermudagrass species. This assumption is based on the data collected by the research team from side-by-side non-transpiring tall fescue and hybrid bermudagrass plots sprayed with glyphosate in southern California (data not published). Different baselines were established for each year to determine their stability over time.

\section{Results}

\subsection{NDVI}

Figure 4 shows the response of both species (dynamics of NDVI values) to the applied irrigation treatments in 2018 and 2019. Table 3 summarizes the results of the statistical analysis for both species in the years 2018 and 2019. For tall fescue, the NDVI values ranged between 0.30 and 0.80 in 2018 and between 0.23 and 0.69 in 2019. The irrigation level $(p<0.001)$ and frequency $(p<0.05)$ had significant effects on NDVI values in 2018. In 2019, only the irrigation level had a significant effect $(p<0.01)$ on turfgrass quality. The interaction between irrigation levels and frequency was not significant in neither of the years. In 2018, the dynamics of NDVI values over time for all treatments were somewhat similar, showing a slight decline as the trial progressed. However, for $83 \%$ $\mathrm{ET}_{\mathrm{o}}$ treatment ( $2 \mathrm{~d} \mathrm{wk}^{-1}$ frequency), a more noticeable reduction in NDVI values was observed toward the end of the experimental period. In 2019, the NDVI values for the lowest irrigation application of $83 \% \mathrm{ET}_{\mathrm{o}}$ started to decline around mid-July for both 3 and $7 \mathrm{~d} \mathrm{w}^{-1}$ irrigation frequency. The NDVI values showed no substantial change for the other irrigation treatments.

For hybrid bermudagrass, the NDVI valued varied between 0.53 and 0.76 in 2018 and between 0.34 and 0.80 in 2019. The irrigation levels had no significant effect on NDVI values in 2018 and 2019 (Table 3). The impact of irrigation frequency was only significant $(p<0.01)$ in 2019. The interaction between irrigation levels and frequency was not significant in either of the years. In 2018, the NDVI for all treatments stayed fairly stable with no substantial fluctuations over time. In 2019, NDVI values increased over time with no noticeable differences between the irrigation treatments (Figure 4). 


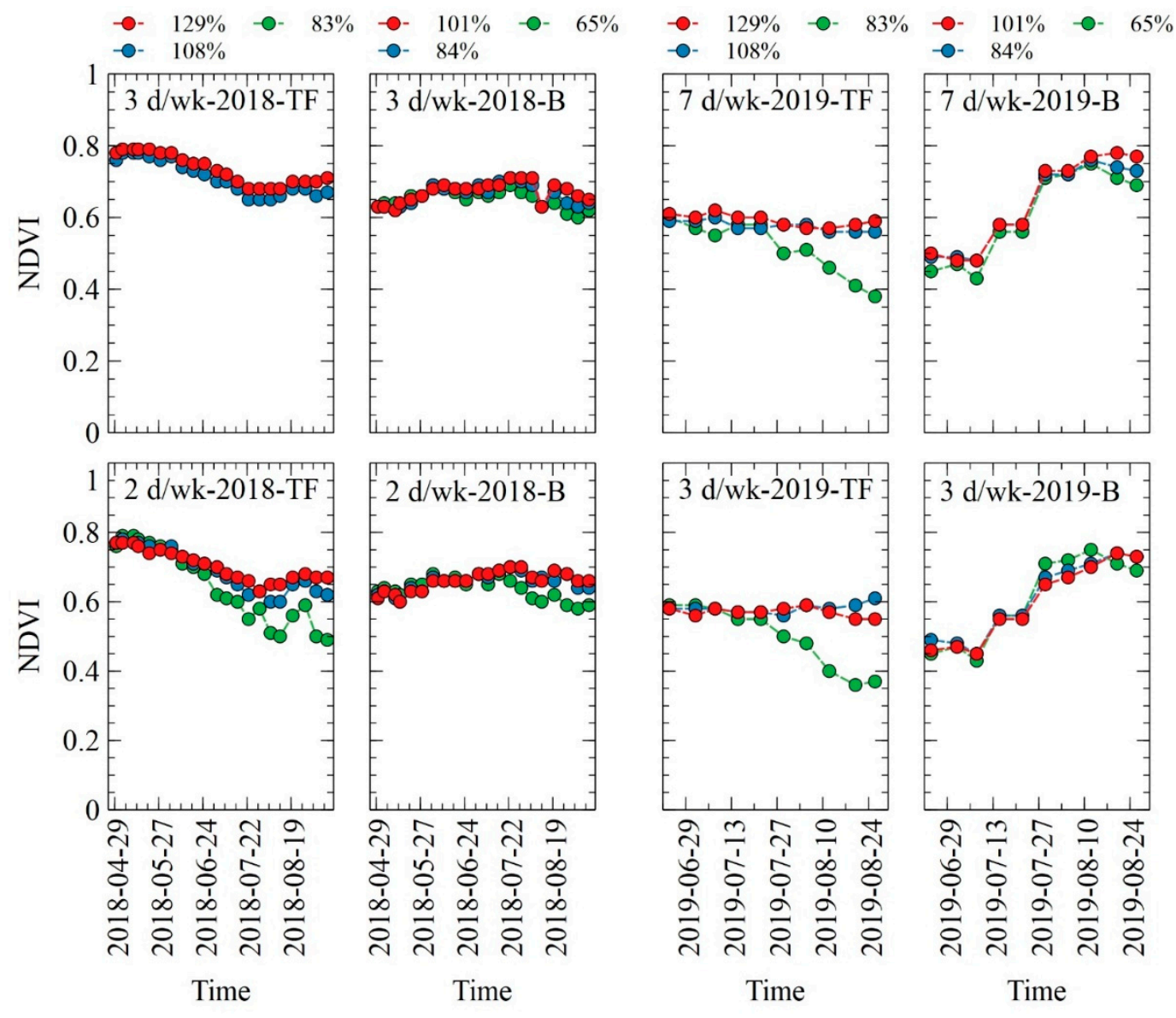

Figure 4. NDVI values showing the response of hybrid bermudagrass and tall fescue turfgrass to varying irrigation levels $\left(\mathrm{ET}_{\mathrm{o}} \%\right)$ and frequency (d/wk: days per week) imposed in 2018 and 2019. TF: tall fescue, B: hybrid bermudagrass.

Table 3. Statistical analysis of the hybrid bermudagrass and tall fescue response (NDVI and canopy temperature) to irrigation treatments imposed in years 2018 and 2019 (each year was analyzed separately).

\begin{tabular}{|c|c|c|c|c|c|c|c|c|c|}
\hline \multicolumn{6}{|c|}{ Tall Fescue } & \multicolumn{4}{|c|}{ Hybrid Bermudagrass } \\
\hline & \multicolumn{2}{|c|}{ NDVI } & \multicolumn{2}{|c|}{ Canopy Temp. } & \multirow[b]{2}{*}{ Treatment } & \multicolumn{2}{|c|}{ NDVI } & \multicolumn{2}{|c|}{ Canopy Temp. } \\
\hline Treatment & 2018 & 2019 & 2018 & 2019 & & 2018 & 2019 & 2018 & 2019 \\
\hline $129 \% \mathrm{ET}_{\mathrm{o}}$ & $0.72 \mathrm{a}$ & $0.59 a$ & $31.8 \mathrm{~b}$ & $37.2 b$ & $101 \% \mathrm{ET}_{\mathrm{o}}$ & $0.66 a$ & $0.62 a$ & $34.5 \mathrm{a}$ & $39.4 a$ \\
\hline $108 \% \mathrm{ET}_{\mathrm{o}}$ & $0.70 \mathrm{a}$ & $0.58 \mathrm{a}$ & $31.9 \mathrm{~b}$ & $37.4 \mathrm{~b}$ & $84 \% \mathrm{ET}_{\mathrm{o}}$ & $0.66 \mathrm{a}$ & $0.62 \mathrm{a}$ & $34.5 \mathrm{a}$ & $39.4 a$ \\
\hline $83 \% \mathrm{ET}_{\mathrm{o}}$ & $0.65 b$ & $0.51 b$ & $33.0 \mathrm{a}$ & $38.1 \mathrm{a}$ & $65 \% \mathrm{ET}_{\mathrm{o}}$ & $0.64 \mathrm{a}$ & $0.59 a$ & $35.0 \mathrm{a}$ & $39.5 a$ \\
\hline Frequency & & & & & Frequency & & & & \\
\hline $2 \mathrm{dw}^{-1}$ & $0.68 b$ & & $32.5 \mathrm{a}$ & & $2 \mathrm{~d} \mathrm{w}^{-1}$ & $0.65 a$ & & $35.0 \mathrm{a}$ & \\
\hline $3 \mathrm{~d} \mathrm{w}^{-1}$ & $0.70 \mathrm{a}$ & $0.55 \mathrm{a}$ & $31.9 \mathrm{~b}$ & $37.8 \mathrm{a}$ & $3 \mathrm{~d} \mathrm{w}^{-1}$ & $0.66 a$ & $0.59 \mathrm{~b}$ & $34.3 b$ & $39.7 \mathrm{a}$ \\
\hline $7 \mathrm{~d} \mathrm{w}^{-1}$ & & $0.56 a$ & & $37.4 \mathrm{a}$ & $7 \mathrm{~d} \mathrm{w}^{-1}$ & & $0.63 a$ & & $39.2 b$ \\
\hline Model effect & 2018 & 2019 & 2018 & 2019 & Model effect & 2018 & 2019 & 2018 & 2019 \\
\hline I & $* * *$ & $* *$ & $* *$ & $*$ & I & NS & NS & NS & NS \\
\hline $\mathrm{F}$ & $*$ & NS & * & NS & $\mathrm{F}$ & NS & $* *$ & $*$ & $*$ \\
\hline $\mathrm{I} \times \mathrm{F}$ & NS & NS & NS & NS & $\mathrm{I} \times \mathrm{F}$ & NS & NS & NS & NS \\
\hline $\mathrm{T}$ & $* * *$ & $* * *$ & $* * *$ & $* * *$ & $\mathrm{~T}$ & $* * *$ & $* * *$ & $* * *$ & $* * *$ \\
\hline $\mathrm{I} \times \mathrm{T}$ & $* * *$ & $* * *$ & NS & NS & $\mathrm{I} \times \mathrm{T}$ & $* * *$ & NS & NS & NS \\
\hline $\mathrm{F} \times \mathrm{T}$ & NS & NS & NS & NS & $\mathrm{F} \times \mathrm{T}$ & NS & NS & $* * *$ & NS \\
\hline $\mathrm{I} \times \mathrm{F} \times \mathrm{T}$ & NS & NS & NS & NS & $\mathrm{I} \times \mathrm{F} \times \mathrm{T}$ & NS & NS & NS & NS \\
\hline
\end{tabular}

NS, ${ }^{* * *}, * *$, and * are non-significant or significant at $p \leq 0.001,0.01$, and 0.05 , respectively. Means sharing a similar letter are not significantly different, based on Turkey's test at $\alpha=0.05$. I, F, and T in the table refer to irrigation levels, frequency, and time (i.e., repeated measures of visual rating each year over time), respectively. 


\subsection{Canopy Temperature and CWSI}

Figure 5 illustrates the tall fescue and hybrid bermudagrass canopy temperature fluctuations over time in response to the irrigation treatments imposed in 2018 and 2019. Table 3 summarizes the results of the statistical analysis for both species in the years 2018 and 2019. The canopy temperature readings were very similar in early and mid-trials in both years for both species across the treatments, while the fluctuations in canopy temperature values over time were more pronounced in 2018. The non-irrigated plot of turfgrass adjacent to the study field had on average $19{ }^{\circ} \mathrm{C}$ and $17{ }^{\circ} \mathrm{C}$ higher canopy temperature than the irrigated plots in 2018 and 2019, respectively.

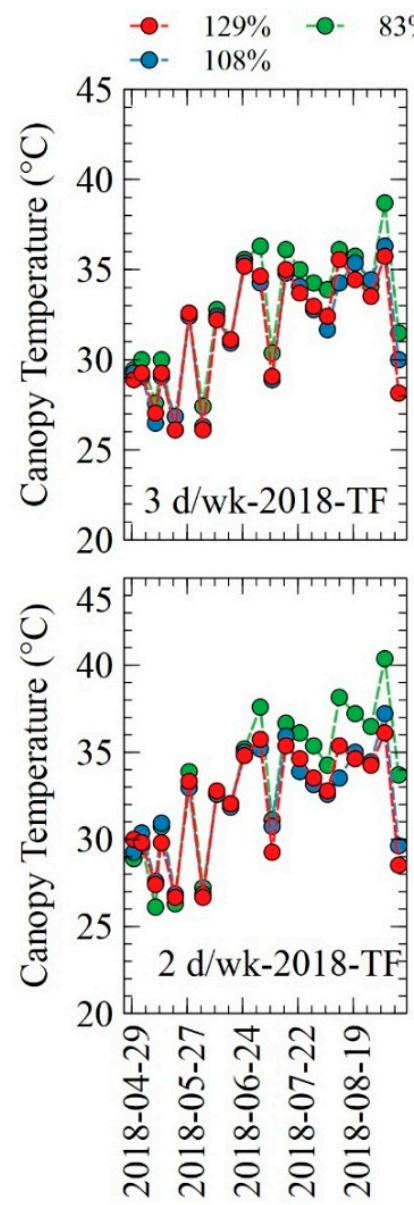

Time
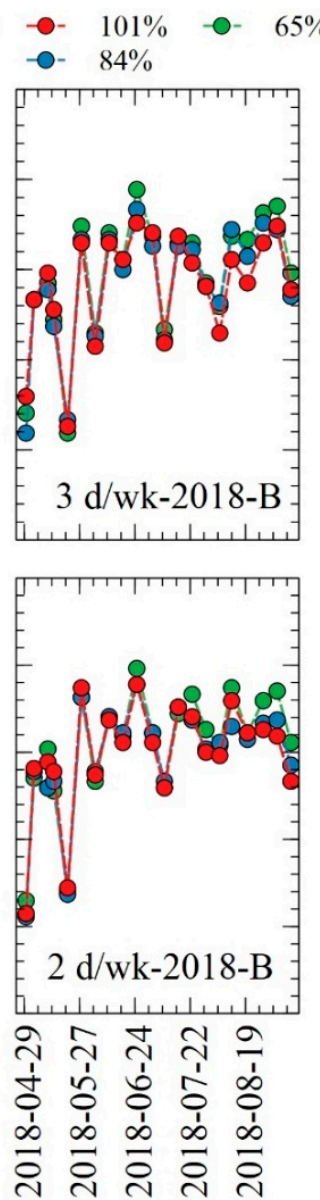

Time
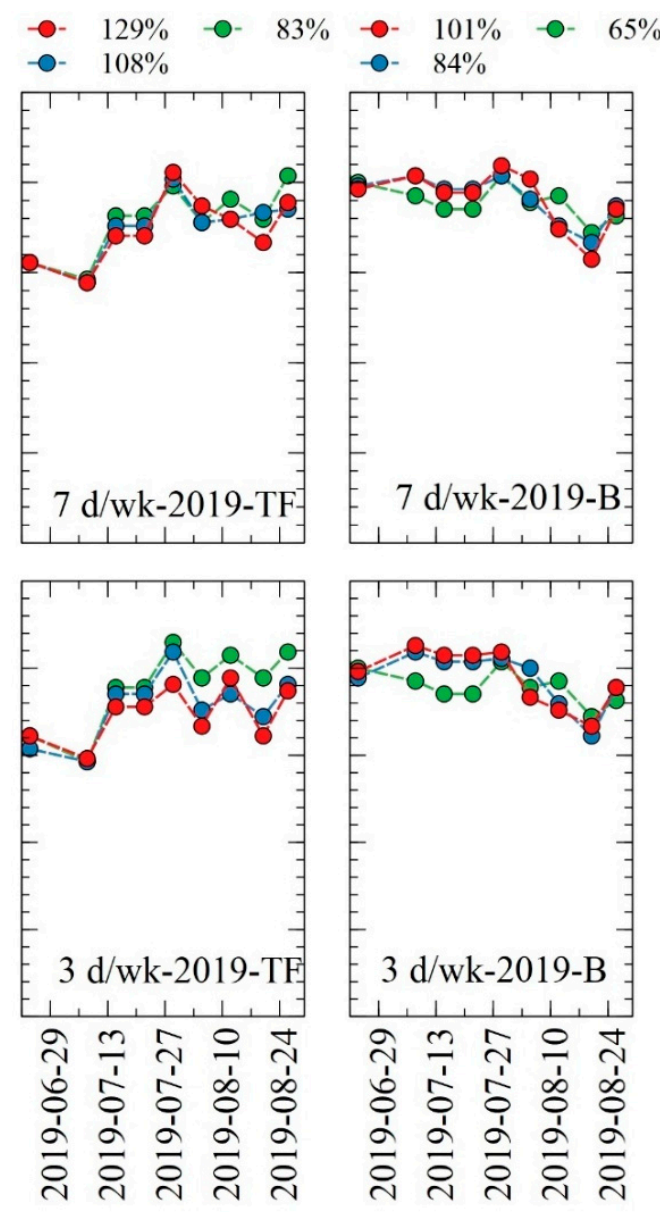

Time

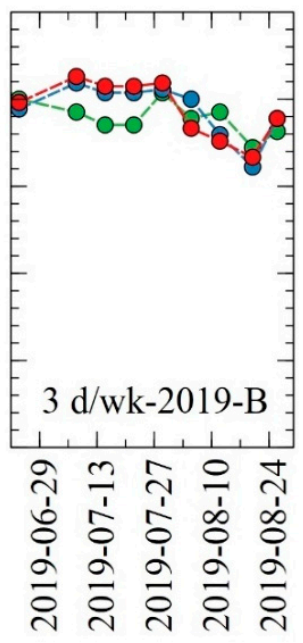

Time

Figure 5. The canopy temperature dynamics of hybrid bermudagrass and tall fescue turfgrass plots under varying irrigation scenarios imposed in 2018 and 2019. d/wk: indicates irrigation frequency in days per week.

For the tall fescue plots, the minimum and maximum canopy temperature values were $24{ }^{\circ} \mathrm{C}$ and $49{ }^{\circ} \mathrm{C}$ in 2018 and $33^{\circ} \mathrm{C}$ and $43{ }^{\circ} \mathrm{C}$ in 2019. Irrigation levels significantly impacted the canopy temperature in $2018(p<0.01)$ and in $2019(p<0.05)$ (Table 3). On average, there was a $1.2{ }^{\circ} \mathrm{C}$ in 2018 and $0.9^{\circ} \mathrm{C}$ in 2019 temperature difference between the highest $\left(129 \% \mathrm{ET}_{\mathrm{o}}\right)$ and lowest $\left(83 \% \mathrm{ET}_{\mathrm{o}}\right)$ irrigation levels. The irrigation frequency had a significant effect in $2018(p<0.05)$ but not in 2019. However, in both years, the canopy temperature was slightly lower for the greater irrigation frequencies. The interaction of the irrigation level and irrigation frequency had no significant effect on canopy temperature values. In both years, $83 \% \mathrm{ET}_{\mathrm{o}}$ treatment started showing higher temperature values toward the end of the trial compared to the other irrigation treatments (Figure 5).

For the hybrid bermudagrass plots, the minimum and maximum canopy temperature values were $23^{\circ} \mathrm{C}$ and $42{ }^{\circ} \mathrm{C}$ in 2018 and $36{ }^{\circ} \mathrm{C}$ and $43^{\circ} \mathrm{C}$ in 2019. The irrigation levels had 
no significant effect on canopy temperature in neither of the years (Table 3). The irrigation frequency significantly impacted the canopy temperature $(p<0.05)$ in both years, such that more frequent irrigation reduced the canopy temperature. The mean canopy temperature was $0.5{ }^{\circ} \mathrm{C}$ in 2018 and $0.1{ }^{\circ} \mathrm{C}$ in 2019 lower in $101 \% \mathrm{ET}_{\mathrm{o}}$ than in $65 \% \mathrm{ET}_{\mathrm{o}}$ treatment. The interaction of the irrigation level and irrigation frequency had no significant effect on canopy temperature values. The $65 \% \mathrm{ET}_{\mathrm{o}}$ treatment in 2018 started showing higher canopy temperature values toward the end of the trial compared to other irrigation levels (Figure 5). However, in 2019, the 65\% $\mathrm{ET}_{\mathrm{o}}$ treatment showed lower canopy temperature early in the trial, but the temperature values were similar across the treatments toward the end of the experiment.

Figure 6 illustrates the lower and upper CWSI baselines established for tall fescue and hybrid bermudagrass in 2018 and 2019. Table 4 summarizes the coefficients for the lower baselines. For the tall fescue plots and $129 \% \mathrm{ET}_{\mathrm{o}}$ treatment, $d t$ (i.e., canopy minus air temperature) varied between -7.1 and $5.2^{\circ} \mathrm{C}$ in 2018 and between -0.6 and $7.9^{\circ} \mathrm{C}$ in 2019. For the $83 \% \mathrm{ET}_{\mathrm{o}}$ treatment, $d t$ varied between -3.8 and $6.4{ }^{\circ} \mathrm{C}$ in 2018 and $-0.6{ }^{\circ} \mathrm{C}$ to $9.2^{\circ} \mathrm{C}$ in 2019. There was a moderate correlation of 0.64 in 2018 and 0.88 in 2019 between $d t$ and VPD for the lower baseline. The slope of the lower baseline was -2.52 in 2018 and -4.22 in 2019. The intercept was two times higher in 2019 compared to 2018.

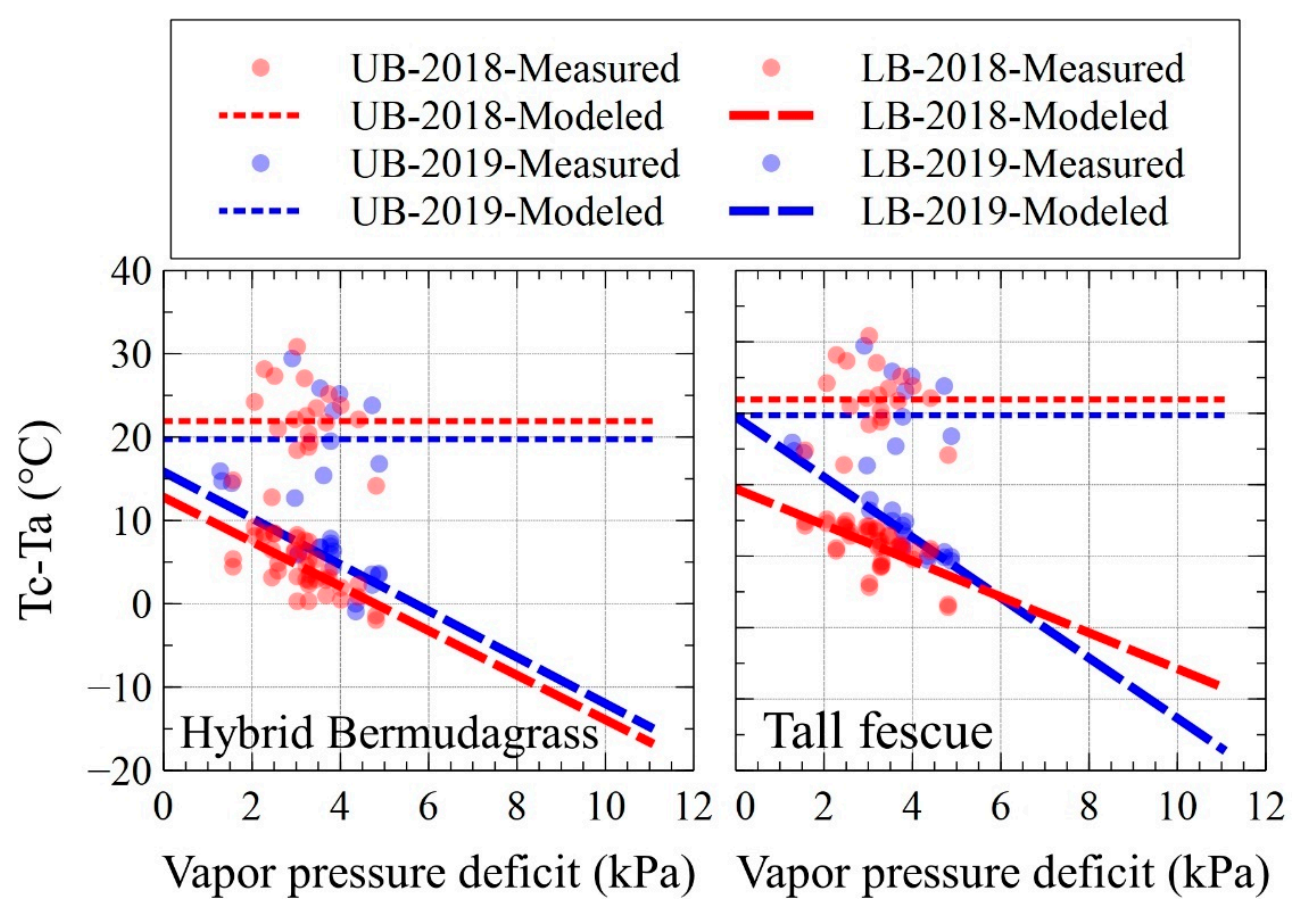

Figure 6. Graphical illustration of the lower (LB) and upper (UB) baselines of canopy temperature (Tc) minus air temperature (Ta) difference versus vapor pressure deficit for hybrid bermudagrass and tall fescue species in central California.

Table 4. Lower CWSI baselines for tall fescue and hybrid bermudagrass.

\begin{tabular}{ccccccc}
\hline & & Tall Fescue & \multicolumn{3}{c}{ Hybrid Bermudagrass } \\
\hline & $\mathbf{a}$ & $\mathbf{b}$ & $\boldsymbol{r}$ & $\mathbf{a}$ & $\mathbf{b}$ & $\boldsymbol{r}$ \\
\hline 2018 & -2.52 & 9.42 & 0.64 & -2.67 & 12.78 & 0.69 \\
2019 & -4.22 & 19.5 & 0.88 & -2.78 & 15.82 & 0.64 \\
\hline
\end{tabular}

$r$ : correlation coefficient; a: slope, b: intercept.

For hybrid bermudagrass, $d t$ varied between -2.0 and $9.2^{\circ} \mathrm{C}$ for the $101 \% \mathrm{ET}_{\mathrm{o}}$ level in 2018 and between -0.9 and $7.8^{\circ} \mathrm{C}$ in 2019 . For the $65 \% \mathrm{ET}_{\mathrm{O}}$ treatment, $d t$ varied between 0.5 and $8.9^{\circ} \mathrm{C}$ in 2018 and between 0.6 and $7.7^{\circ} \mathrm{C}$ in 2019 . The correlation between $d t$ and 
VPD for hybrid bermudagrass was 0.69 in 2018 and 0.64 in 2019. The lower CWSI baselines had a somewhat similar slope in both years, but the intercept was $3{ }^{\circ} \mathrm{C}$ higher in 2019 .

The upper baseline (set to mean $d t$ for the severely stressed non-irrigated tall fescue plot) was equal to $21.9 \pm 4.7^{\circ} \mathrm{C}$ (mean \pm standard deviation, SD) in 2018 and $19.7 \pm 5.3^{\circ} \mathrm{C}$ in 2019. The combined upper baseline data for both years had a mean \pm standard deviation $d t$ of $21.1 \pm 4.9^{\circ} \mathrm{C}$.

Figure 7 depicts the dynamics of tall fescue and hybrid bermudagrass CWSI over time in response to the irrigation treatments imposed in 2018 and 2019. The CWSI dynamics over time for both species are similar to the canopy temperature fluctuations (Figure 8), with minor differences mainly toward the end of 2019. For tall fescue, the CWSI values varied between -0.3 and 0.29 in 2018 and between -0.59 and 0.27 in 2019. For hybrid bermudagrass, the CWSI values ranged from -0.34 to 0.24 in 2018 and from -0.26 to 0.56 in 2019.
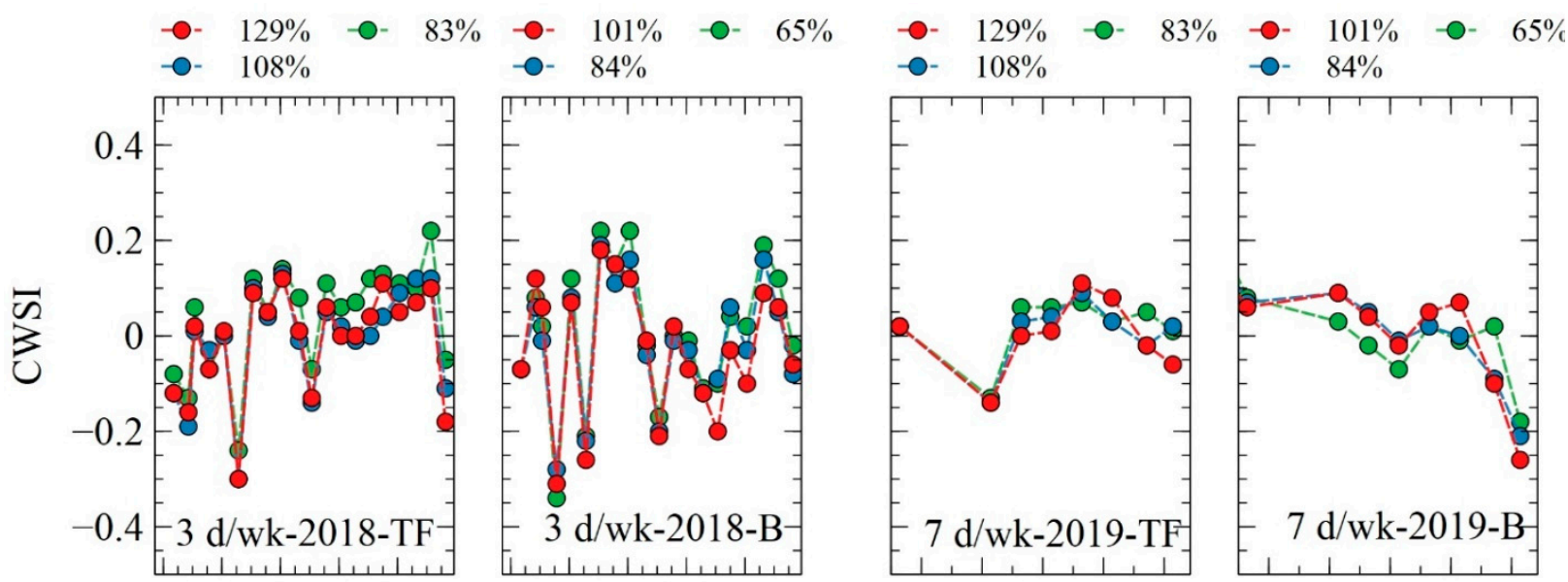

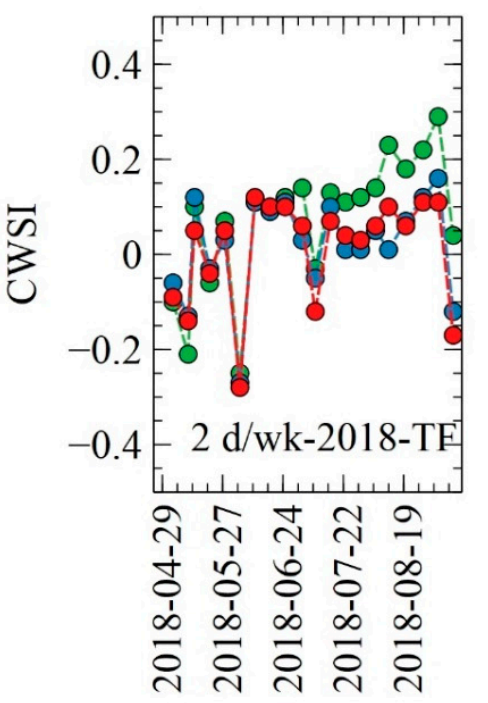

Time

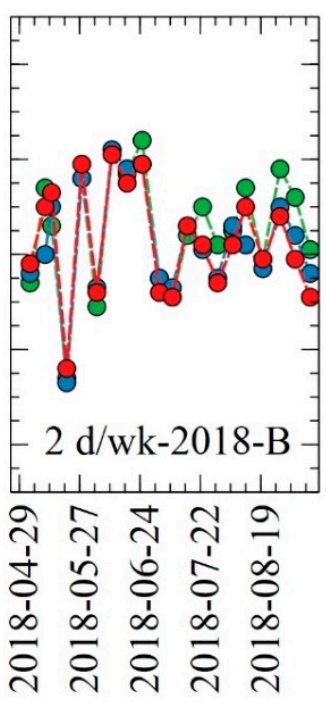

Time

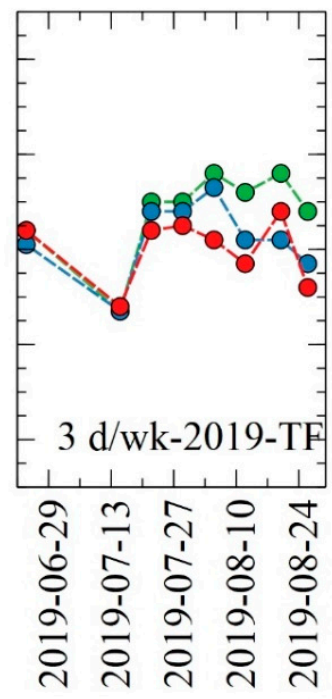

Time
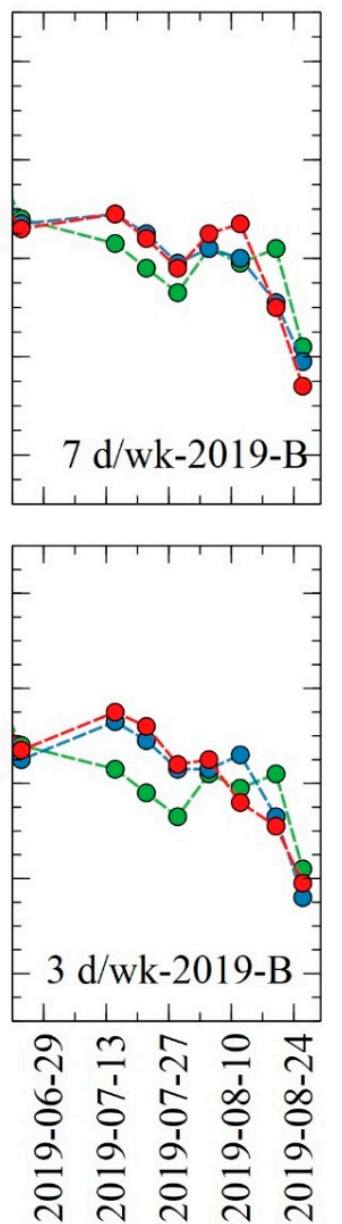

Time

Figure 7. The crop water stress index (CWSI) dynamics for the hybrid bermudagrass (B) and tall fescue (TF) turfgrass plots under varying irrigation scenarios imposed in 2018 and 2019. d/wk: indicated irrigation frequency in days per week. 

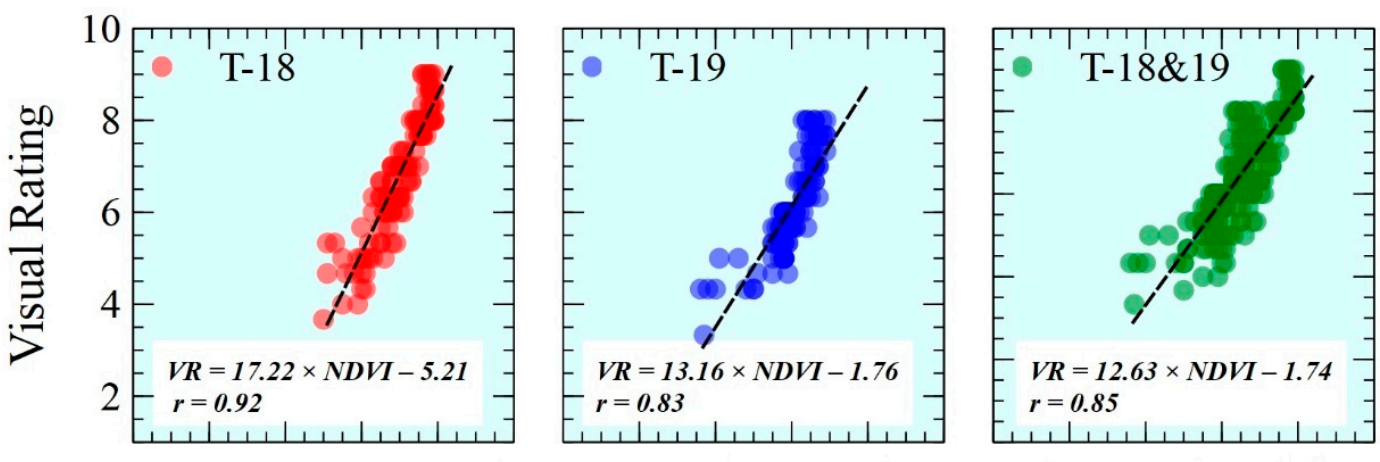

$\begin{array}{llllll}0 & 0.2 & 0.4 & 0.6 & 0.8 & 1\end{array}$
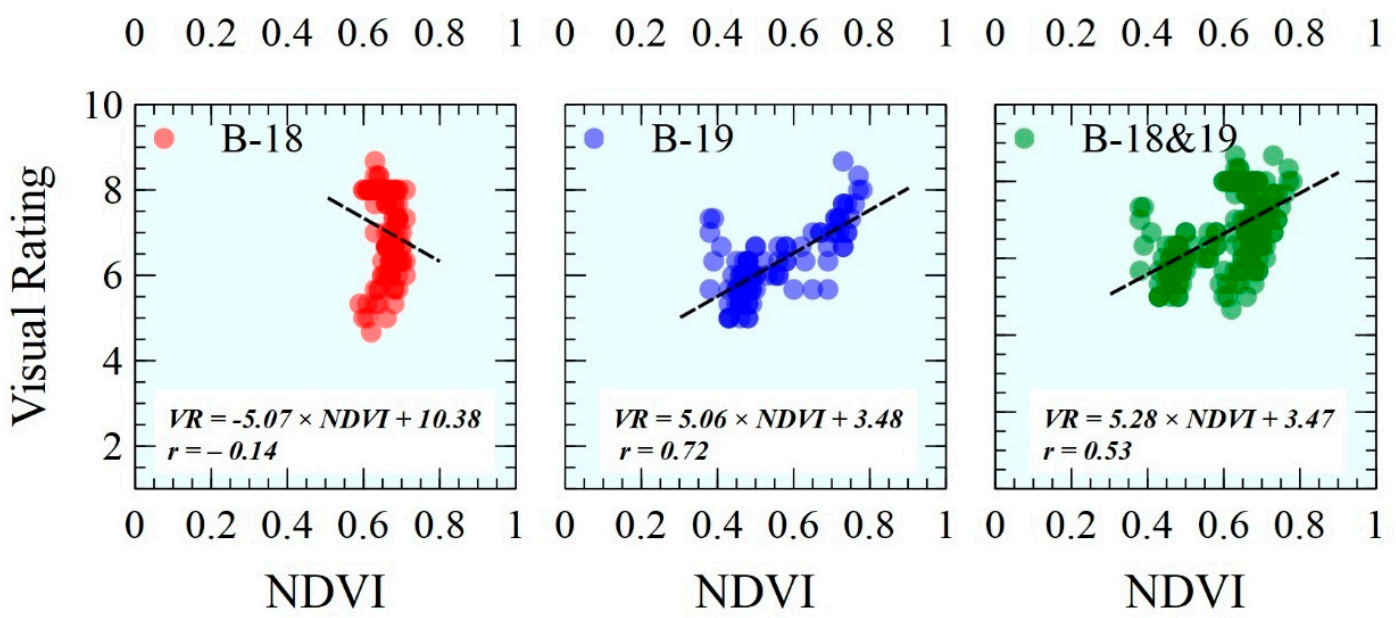

Figure 8. Relationship between visual rating (VR) and NDVI data collected in 2018 and 2019 from hybrid bermudagrass (B) and tall fescue $(\mathrm{T})$ irrigation trials conducted at the University of California Kearney Research and Extension Center.

\section{Discussion}

\subsection{NDVI and Visual Rating}

For tall fescue, the NDVI values ranged between 0.30 and 0.80 in 2018 and between 0.23 and 0.69 in 2019. The lower NDVI values in 2019 agree with the lower VR values reported in the companion paper [23]. This is attributed to the minimal fertilizer application in 2019, diminishing growth and greenness of tall fescue. NDVI and VR were well correlated for tall fescue in $2018(r=0.92)$ and in $2019(r=0.83)$. Bremer et al. [27] conducted a 3-year study near Manhattan, Kansas and reported $r$-value of 0.75 between VR and NDVI values of 'Dynasty' tall fescue. The slope of the intercept of fitted regression lines in our study differed between 2018 and 2019. Bremer et al. [27] also obtained different models for each turfgrass in each year of their study and mentioned that as a potential practical limitation to estimate visual quality using NDVI values.

For hybrid bermudagrass, the NDVI values varied between 0.53 and 0.76 in 2018 and between 0.34 and 0.8 in 2019. In 2019, the NDVI values increased as the trial progressed in response to the late green-up of hybrid bermudagrass through June and a fertilizer application in mid-July. This trend agrees with an increase in VR values reported in the companion paper [23]. The correlation between NDVI and VR was moderate $(r=0.72)$ in 2019 , which is on the lower end of the reported values in the literature. We [8] obtained $r=0.84$ between NDVI and VR values for hybrid bermudagrass based on a 3-year composite dataset in Riverside, California. Bell et al. [34] conducted a two-year study and reported an annual $r$ of 0.8 between NDVI and VR of hybrid bermudagrass (49 cultivars) in Stillwater, Oklahoma. Trenholm et al. [35] studied three hybrid bermudagrass cultivars in Griffin, Georgia and reported $r$-values ranging from 0.70 to 0.90 between turfgrass VR and NDVI.

In 2018, no meaningful correlation was observed between NDVI and VR values, which is attributed to the narrow NDVI range of variation (0.53-0.76). However, the range of 
VR values was relatively wide (4-9) in 2018 [23]. We also noticed (data not presented in this study) the mean coefficient of variation between replications of the same irrigation treatment on average was $60 \%$ higher for VR values than NDVI values. The quality variation among replications of the same irrigation treatment is expected to be minimal. These results suggest that NDVI can be a more stable and repeatable parameter than VR to assess the overall response of the turfgrass to irrigation regimes.

Our results suggest the NDVI values of $0.6-0.65$ for tall fescue and 0.5 for hybrid bermudagrass to maintain acceptable quality $(\mathrm{VR}=6)$ in the central California region. We [8] obtained NDVI of 6 as the minimum threshold for hybrid bermudagrass in inland southern California. Further investigation is needed to verify the thresholds obtained in this study, particularly for hybrid bermudagrass, since the recommendation is only based on 2019 data.

\subsection{Canopy Temperature and CWSI}

The reported results in our companion paper [23] show that when water conservation is concerned, hybrid bermudagrass is the superior species since it can sustain its quality better than tall fescue when irrigation is limited, as expected. The tall fescue treatments received more water (equal to roughly $20 \% \mathrm{ET}_{\mathrm{o}}$ ) than the hybrid bermudagrass and still could not continuously maintain the same VR values during the summer months in central California. Culpepper et al. [36] conducted two greenhouse trials in Texas, USA, to compare the response of bermudagrass, buffalograss (Buchloe dactyloides (Nutt.) Engelm.), and tall fescue to water deficit. They reported that tall fescue ( $C_{3}$ cool-season turfgrass) under heat and drought stress showed the most rapid decline in quality and photosynthetic rates compared to the $C_{4}$ warm-season grasses, demonstrating the benefits of the $C_{4}$ versus $C_{3}$ photosynthetic pathway.

On the other hand, the result of this study showed that the mean canopy temperature was higher for hybrid bermudagrass than tall fescue across the treatments in both years. On average, in both years, the hybrid bermudagrass plots were $1.6^{\circ} \mathrm{C}$ warmer than tall fescue plots when they received the same irrigation treatments of $83-84 \% \mathrm{ET}_{\mathrm{o}}$. Further comparative studies are needed to evaluate the potential water conservation and cooling benefits of irrigated warm-season and cool-season species versus alternative groundcover species in California.

For the same irrigation levels, increasing irrigation frequency (number of watering days) slightly $\left(0.6{ }^{\circ} \mathrm{C}\right.$ on average $)$ but consistently decreased canopy temperature without compromising the turfgrass quality. We attribute this to a more pronounced evaporative cooling associated with higher irrigation frequencies while minimizing runoff and deep percolation. Consequently, as suggested in the companion paper [23], when ET-based smart controllers are used, we recommend no watering restrictions so the controller can adjust the watering days based on the actual weather conditions and evaporative demand. Then, a minimum deficit threshold should be programmed to avoid unnecessary evaporative loss due to light irrigation applications.

The correlation between $d t$ and VPD for well-watered treatments (lower baselines of CWSI) was moderate in this study. We observed $r$-values of 0.64 and 0.88 for tall fescue and 0.69 and 0.64 for hybrid bermudagrass in two years of our research. Jalali-Farahani et al. [37] reported $r=0.87$ between VPD and $d t$ for well-watered hybrid bermudagrass in Tucson, Arizona. Payero et al. [38] observed $r$-values ranging from 0.92 to 0.95 between $d t$ and VPD at different solar radiation levels for tall fescue grass at Kimberly, Idaho. Taghvaiean et al. [14] conducted a field study in Berthoud, Colorado, on multiple turfgrass species and mentioned that the effect of solar radiation is negligible when $d t$ data are collected under the clear sky and close to solar noon. On the other hand, multiple studies reported a high correlation between CWSI and solar radiation $[37,38]$. We leave it to future studies to determine the potential improvement in hybrid bermudagrass and tall fescue CWSI lower baselines developed in this study when additional weather parameters such as solar radiation are considered. 
The CWSI values are expected to vary from 0 to 1 , representing no transpiration and maximum transpiration rates, respectively. In our study, the CWSI values ranged from -0.34 to 0.56 for hybrid bermudagrass and -0.59 to 0.29 for tall fescue. Jalali-Farahani [37] reported violations of the theoretical range one-fourth of the time. In addition, Al-Faraj et al. [39] studied the CWSI of 'Falcon' tall fescue in a controlled environment and concluded that there is no easy way to ensure that the empirical CWSI consistently stays within the theoretical range of zero (no stress) and one (severe water stress).

In our study, the mean \pm SD CWSI values were $0 \pm 0.13$ and $0 \pm 0.10$ for wellwatered tall fescue $\left(129 \% \mathrm{ET}_{\mathrm{o}}\right)$ and hybrid bermudagrass $\left(101 \% \mathrm{ET}_{\mathrm{o}}\right)$, respectively. JalaliFarahani [37] reported a mean CWSI value of -0.02 and an SD of 0.28 for well-watered hybrid bermudagrass. In our study, for the $65 \% \mathrm{ET}_{\mathrm{o}}$ treatment, the mean $\pm \mathrm{SD}$ hybrid bermudagrass CWSI was $0.1 \pm 0.12$. Somewhat similar to our results, Emekli et al. [15] reported 0.09 and 0.10 as seasonal mean CWSI of hybrid bermudagrass under $100 \%$ pan evaporation $\left(\approx 75 \% \mathrm{ET}_{\mathrm{o}}\right)$ and $75 \%$ pan evaporation $\left(\approx 56 \% \mathrm{ET}_{\mathrm{o}}\right)$ irrigation treatments in Antalya, Turkey. They reported a good relationship between VR and CWSI and suggested a CWSI of approximately 0.1 to maintain hybrid bermudagrass quality. However, we can not recommend a CWSI threshold to maintain turf quality in the acceptable range because of the high variability of CWSI values over time and their low correlation with VR values (not reported in this study). The canopy temperature and CWSI dynamics were very similar in this study, and CWSI did not provide much extra information regarding the dynamic impact of irrigation regimes on turfgrass quality.

\section{Conclusions}

It is vital to establish landscape irrigation water conservation strategies while determining its impact on the cooling effect of irrigated landscape in the US southwest. Our two-year field study focused on ground-based remote sensing of hybrid bermudagrass and tall fescue under varying irrigation scenarios autonomously imposed by an ET-based smart irrigation controller in central California. When the NDVI range of variation was high, it was well correlated to VR values for both species. Overall, the NDVI showed less variability between replications of the same treatments for both species when compared to VR. This finding suggests NDVI as a consistent and objective proxy of overall turfgrass quality in response to varying irrigation regimes. Hybrid bermudagrass was a superior species to tall fescue when water conservation was concerned. However, it showed $1.6^{\circ} \mathrm{C}$ higher canopy temperature than tall fescue when it received the same amount of water. Our results suggested the NDVI values of $0.6-0.65$ for tall fescue and 0.5 for hybrid bermudagrass to maintain acceptable quality $(\mathrm{VR}=6)$ in the central California region. Further investigation is needed to verify the thresholds obtained in this study, particularly for hybrid bermudagrass, since the recommendation is only based on 2019 data. No CWSI minimum threshold could be identified to maintain the quality of the selected species due to its high variability and low correlation with VR. Given their ease of use for small plot data collection, we selected handheld sensors in this study to measure canopy temperature and NDVI. However, collecting data from larger irrigated areas in practice using handheld sensors might be time-consuming and challenging. Further studies are needed to explore the utility of unmanned aerial vehicles and advanced multispectral and thermal cameras and compare their readings with handheld sensors used in this study.

Author Contributions: Conceptualization, A.H.; methodology, A.H.; software, A.H., A.S. (Amninder Singh), and A.S. (Anish Sapkota); validation, A.H., A.S. (Amninder Singh), and A.S. (Anish Sapkota); formal analysis, A.H., M.R., A.S. (Amninder Singh) and A.S. (Anish Sapkota); investigation, A.H., M.R., A.S. (Amninder Singh) and A.S. (Anish Sapkota); resources, A.H. and M.R; data curation, A.H., M.R., A.S. (Amninder Singh) and A.S. (Anish Sapkota); writing-original draft preparation, A.H.; writing-review and editing, A.H., M.R., A.S. (Amninder Singh) and A.S. (Anish Sapkota); visualization, A.H.; supervision, A.H.; project administration, A.H. and M.R; funding acquisition, A.H. and M.R. All authors have read and agreed to the published version of the manuscript. 
Funding: This study was supported by the University of California Division of Agriculture and Natural Resources competitive grant (ID\#: 17-5021) and by the United States Geological Survey (ID\#: 2017CA371B).

Data Availability Statement: Not applicable.

Conflicts of Interest: The authors declare no conflict of interest.

\section{References}

1. Cooley, H.; Gleick, P.H. Urban Water-Use Efficiencies: Lessons from United States Cities; Island Press: Washington, DC, USA, 2009.

2. Monteiro, J.A. Ecosystem services from turfgrass landscapes. Urban For. Urban Green. 2017, 26, 151-157. [CrossRef]

3. Blonquist, J., Jr.; Jones, S.B.; Robinson, D. Precise irrigation scheduling for turfgrass using a subsurface electromagnetic soil moisture sensor. Agric. Water Manag. 2006, 84, 153-165. [CrossRef]

4. Cardenas-Lailhacar, B.; Dukes, M.D.; Miller, G.L. Sensor-based automation of irrigation on bermudagrass, during wet weather conditions. J. Irrig. Drain. Eng. 2008, 134, 120-128. [CrossRef]

5. Davis, S.L.; Dukes, M.D. Importance of ET controller program settings on water conservation potential. Appl. Eng. Agric. 2016, 32, 251-262.

6. Grabow, G.L.; Ghali, I.E.; Huffman, R.L.; Miller, G.L.; Bowman, D.; Vasanth, A. Water application efficiency and adequacy of ET-based and soil moisture-based irrigation controllers for turfgrass irrigation. J. Irrig. Drain. Eng. 2013, 139, 113-123. [CrossRef]

7. Qualls, R.J.; Scott, J.M.; DeOreo, W.B. Soil moisture sensors for urban landscape irrigation: Effectiveness and reliability. JAWRA J. Am. Water Resour. Assoc. 2001, 37, 547-559. [CrossRef]

8. Haghverdi, A.; Singh, A.; Sapkota, A.; Reiter, M.; Ghodsi, S. Developing irrigation water conservation strategies for hybrid bermudagrass using an evapotranspiration-based smart irrigation controller in inland southern California. Agric. Water Manag. 2021, 245, 106586. [CrossRef]

9. Cardenas, B.; Dukes, M.D. Soil moisture sensor irrigation controllers and reclaimed water; Part. I: Field-plot study. Appl. Eng. Agric. 2016, 32, 217-224.

10. Cardenas, B.; Dukes, M.D. Soil moisture sensor irrigation controllers and reclaimed water; Part. II: Residential evaluation. Appl. Eng. Agric. 2016, 32, 225-234.

11. Chen, W.; Lu, S.; Pan, N.; Wang, Y.; Wu, L. Impact of reclaimed water irrigation on soil health in urban green areas. Chemosphere 2015, 119, 654-661. [CrossRef] [PubMed]

12. An, N.; Goldsby, A.L.; Price, K.P.; Bremer, D.J. Using hyperspectral radiometry to predict the green leaf area index of turfgrass. Int. J. Remote Sens. 2015, 36, 1470-1483. [CrossRef]

13. Johnson, T.D.; Belitz, K. A remote sensing approach for estimating the location and rate of urban irrigation in semi-arid climates. J. Hydrol. 2012, 414, 86-98. [CrossRef]

14. Taghvaeian, S.; Chávez, J.L.; Hattendorf, M.J.; Crookston, M.A. Optical and thermal remote sensing of turfgrass quality, water stress, and water use under different soil and irrigation treatments. Remote Sens. 2013, 5, 2327-2347. [CrossRef]

15. Emekli, Y.; Bastug, R.; Buyuktas, D.; Emekli, N.Y. Evaluation of a crop water stress index for irrigation scheduling of bermudagrass. Agric. Water Manag. 2007, 90, 205-212. [CrossRef]

16. Chen, Y.-J.; McFadden, J.P.; Clarke, K.C.; Roberts, D.A. Measuring spatio-temporal trends in residential landscape irrigation extent and rate in Los Angeles, California Using SPOT-5 satellite imagery. Water Resour. Manag. 2015, 29, 5749-5763. [CrossRef]

17. Irmak, S.; Haman, D.Z.; Bastug, R. Determination of crop water stress index for irrigation timing and yield estimation of corn. Agron. J. 2000, 92, 1221-1227. [CrossRef]

18. Shashua-Bar, L.; Pearlmutter, D.; Erell, E. The cooling efficiency of urban landscape strategies in a hot dry climate. Landsc. Urban Plan. 2009, 92, 179-186. [CrossRef]

19. Bonfils, C.; Lobell, D. Empirical evidence for a recent slowdown in irrigation-induced cooling. Proc. Natl. Acad. Sci. USA 2007, 104, 13582-13587. [CrossRef] [PubMed]

20. Broadbent, A.M.; Coutts, A.M.; Tapper, N.J.; Demuzere, M. The cooling effect of irrigation on urban microclimate during heatwave conditions. Urban Clim. 2017, 23, 309-329. [CrossRef]

21. Wang, C.; Wang, Z.-H.; Yang, J. Urban water capacity: Irrigation for heat mitigation. Comput. Environ. Urban Syst. 2019, 78, 101397. [CrossRef]

22. Idso, S.B.; Jackson, R.D.; Pinter, P.J., Jr.; Reginato, R.J.; Hatfield, J.L. Normalizing the stress-degree-day parameter for environmental variability. Agric. Meteorol. 1981, 24, 45-55. [CrossRef]

23. Haghverdi, A.; Reiter, M.; Sapkota, A.; Singh, A. Hybrid. Bermudagrass and Tall fescue Turfgrass Irrigation in Central California: I. Assessment of Visual Quality, Soil Moisture and Performance of an ET-based Smart Controller. Agronomy 2021, 11, 1666. [CrossRef]

24. Leinauer, B.; VanLeeuwen, D.M.; Serena, M.; Schiavon, M.; Sevostianova, E. Digital image analysis and spectral reflectance to determine turfgrass quality. Agron. J. 2014, 106, 1787-1794. [CrossRef]

25. Bell, G.E.; Martin, D.L.; Wiese, S.G.; Dobson, D.D.; Smith, M.W.; Stone, M.L.; Solie, J.B. Vehicle-mounted optical sensing: An. objective means for evaluating turf quality. Crop Sci. 2002, 42, 197-201. [CrossRef]

26. Horst, G.; Engelke, M.; Meyers, W. Assessment of visual evaluation techniques ${ }^{1}$. Agron. J. 1984, 76, 619-622. [CrossRef] 
27. Bremer, D.J.; Lee, H.; Su, K.; Keeley, S.J. Relationships between normalized difference vegetation index and visual quality in cool-season turfgrass: I. Variation among species and cultivars. Crop Sci. 2011, 51, 2212-2218. [CrossRef]

28. Bremer, D.J.; Lee, H.; Su, K.; Keeley, S.J. Relationships between normalized difference vegetation index and visual quality in cool-season turfgrass: II. Factors affecting NDVI and its component reflectances. Crop Sci. 2011, 51, 2219-2227. [CrossRef]

29. Haghverdi, A.; Najarchi, M.; Öztürk, H.S.; Durner, W. Studying Unimodal, Bimodal, PDI and Bimodal-PDI Variants of Multiple Soil Water Retention Models: I. Direct Model. Fit. Using the Extended Evaporation and Dewpoint Methods. Water 2020, 12, 900. [CrossRef]

30. Hargreaves, G.H.; Samani, Z.A. Reference crop evapotranspiration from temperature. Appl. Eng. Agric. 1985, 1, 96-99. [CrossRef]

31. Sanders, J. Veusz-a Scientific Plotting Package; 2008; Available online: https:/ /veusz.github.io/ (accessed on 28 August 2021).

32. Morris, K.N.; Shearman, R.C. NTEP turfgrass evaluation guidelines. In Proceedings of the NTEP Turfgrass Evaluation Workshop, Beltsville, MD, USA, 17 October 1998; pp. 1-5.

33. Jackson, R.D.; Idso, S.B.; Reginato, R.J.; Pinter, P.J., Jr. Canopy temperature as a crop water stress indicator. Water Resour. Res. 1981, 17, 1133-1138. [CrossRef]

34. Bell, G.E.; Martin, D.L.; Koh, K.; Han, H.R. Comparison of turfgrass visual quality ratings with ratings determined using a handheld optical sensor. HortTechnology 2009, 19, 309-316. [CrossRef]

35. Trenholm, L.; Carrow, R.; Duncan, R. Relationship of multispectral radiometry data to qualitative data in turfgrass research. Crop Sci. 1999, 39, 763-769. [CrossRef]

36. Culpepper, T.; Young, J.; Montague, D.T.; Sullivan, D.; Wherley, B. Physiological responses in C3 and C4 turfgrasses under soil water deficit. HortScience 2019, 54, 2249-2256. [CrossRef]

37. Jalali-Farahani, H.; Slack, D.C.; Kopec, D.M.; Matthias, A.D. Crop water stress index models for Bermudagrass turf: A comparison. Agron. J. 1993, 85, 1210-1217. [CrossRef]

38. Payero, J.; Neale, C.; Wright, J. Non-water-stressed baselines for calculating crop water stress index (CWSI) for alfalfa and tall fescue grass. Trans. ASAE 2005, 48, 653-661. [CrossRef]

39. Al-Faraj, A.; Meyer, G.E.; Horst, G.L. A crop water stress index for tall fescue (Festuca arundinacea Schreb.) irrigation decisionmaking-A traditional method. Comput. Electron. Agric. 2001, 31, 107-124. [CrossRef] 